
administrators and citizens

\title{
Whither Weiwen?
}

Stability maintenance in the 18th Party Congress era

\section{Karita Kan}

\section{OpenEdition \\ Journals}

\section{Electronic version}

URL: http://journals.openedition.org/chinaperspectives/6120

DOI: $10.4000 /$ chinaperspectives. 6120

ISSN: 1996-4617

\section{Publisher}

Centre d'étude français sur la Chine contemporaine

\section{Printed version}

Date of publication: 15 March 2013

Number of pages: 87-93

ISSN: 2070-3449

\section{Electronic reference}

Karita Kan, « Whither Weiwen? », China Perspectives [Online], 2013/1 | 2013, Online since 01 March 2013, connection on 15 September 2020. URL : http://journals.openedition.org/chinaperspectives/ 6120 


\title{
CefC News Analysis
}

\section{Whither Weiwen?}

\author{
Stability maintenance in the $18^{\text {th }}$ Party Congress era
}

\author{
KARITA KAN
}

A $s$ the dust settles on the intergenerational transfer of power accomplished by the Chinese Communist Party after protracted factional struggles and intense behind-the-door bargaining, the clamour for political reform is growing louder yet. Critics have looked back upon the last decade presided over by $\mathrm{Hu}$ Jintao and Wen Jiabao with disappointment. Study Times editor DengYuwen penned a damning critique listing ten grave problems (shida wenti 十大问题) as the pair's political legacy (zhengzhi yichan 政治遗产), stating that the problems engendered in the past decade may well outweigh the achievements. (1) Writing in Foreign Affairs, Damien Ma blames the administration for leaving behind "a political environment that is likely more corrupt and stifling than the relatively entrepreneurial and liberal era of the 1990s." (2) China Watcher David Shambaugh describes Hu as "an arch-conservative, cautious, risk-averse, stability-obsessed apparatchik." (3) Gao Wenqian, senior advisor of Human Rights in China, goes further in suggesting that the departing president's "greatest political legacy is stability maintenance with an iron fist." (4)

Indeed, weiwen, the shorthand for stability maintenance in Chinese (weihu wending 维护稳定), has become closely associated with the suppressive governance approach of the Hu-Wen administration and the drastic expansion of the political-legal and public security apparatus that took place under its supervision. First used by Deng Xiaoping and injected into the official discourse with its coming-of-age appearance in the headline of People's Daily - "Stability above all" (wending yadao yiqie 稳定压倒一切) - on the first year anniversary of the 1989 Tiananmen crackdown, the currency of the term wending has coincided with major social conflicts such as the 1999 nationwide campaign against members of the outlawed Falun Gong. (5) But it was from the mid-2000s onwards, in the $17^{\text {th }}$ Party Congress era in tandem with Hu's slogan of building a "harmonious society" (hexie shehui 和谐社会), that weiwen visibly gained in rhetorical ascendance and evolved into an overarching national priority.

The connotation of the term has since grown irreversibly negative as the security-driven state employed high-handed means of violence against its own citizens in the name of preserving stability. The Chongqing fallout, and the subsequent exposure of the excesses of Bo Xilai and his security aide Wang Lijun's strong-fisted campaigns, has nonetheless created an exceptional window of opportunity for reining in the burgeoning power of the political-legal apparatus and for critical re-examination of the enshrined weiwen approach. As we enter the $18^{\text {th }}$ Party Congress era, are we looking at any signs of change? This paper suggests that despite hints of reform, re- cent appointments show that the central elite remains preoccupied with stability concerns and that resistance to change remains strong at both the central and local levels of government. The apparent scaling back of the political-legal apparatus has been accompanied by the parallel rise of the social management regime, which may become a reinvented form of social control. There are nonetheless encouraging signs towards reforming institutions of violence complicit in disciplining "misbehaving" citizens, but meaningful change would require fundamental reform in how successful governance is defined and measured.

\section{Weakened political-legal apparatus?}

The announcement of the new line-up of the Politburo Standing Committee (PSC) in November 2012 concluded months of speculation with a list of names that ultimately thwarts the hopes of reformists. Not only are the relatively liberal Wang Yang and Li Yuanchao not in the top seven, but many in the new PSC enjoy close ties with former president jiang Zemin, demonstrating the triumph of political conservatism and the influence of Party elders. Nonetheless, one important indication of progress can be found in the reduction of the size of the PSC from nine to seven members, which has meant the effective downgrading of the internal security portfolio. The Secretary of the Central Politics and Law Commission, or the zhengfawei (政法委), will no longer serve on China's top decision-making organ but only share a seat on the Politburo with 24 other members. This demotion, to say the least, represents "a very big rebuke" to former security tsar Zhou Yongkang, who had significantly expanded his law enforcement empire during his five-year reign. ${ }^{(6)}$

1. Deng Yuwen, "Hu Wen de zhengzhi yichan" (The political legacy of Hu and Wen), Caijing, September 2012, www.politicalchina.org/newsinfo.asp? Newsid=226783 (consulted on 25 January 2013). English translation of Deng's article available at The China Story, www.thechinastory.org/ 2012/09/the-ten-grave-problems-facing-china/ (consulted on 25 January 2013).

2. Damien Ma, "Before and After Hu," Foreign Affairs, 7 November 2012, www.foreign affairs.com/articles/138419/damien-ma/before-and-after-hu (consulted on 25 January 2013).

3. William Wan, "China's Hu seeks to exert influence long after he leaves power," Washington Post, 6 November 2012

4. Human Rights in China, "Dancing in Shackles: On Xi linping and the $18^{\text {th }}$ Party Congress," China Rights Forum, December 2012, www.hrichina.org/crf/article/6428 (consulted on 25 January 2013).

5. On the usage of the term weiwen in reform China, see the detailed analysis by Qian Gang at China Media Project, http://cmp.hku.hk/2012/09/14/27074/ (consulted on 25 January 2013).

6. Shi Jiangtao, "Beijing begins the big political reshuffle," South China Morning Post (hereafter SCMP), 20 November 2012 
The powerful zhengfawei, in addition to being in charge of the Ministry of Public Security (i.e. the police), the Ministry of State Security (i.e. the secret police), the Procuratorate, and the courts, exercises control over the people's militia and the People's Armed Police (i.e. paramilitary force responsible for civilian policing) while also overseeing "unofficial" security forces such as citizen informants hired by local governments. ${ }^{(7)} \mathrm{A}$ recent Yanhuang Chunqiu report shows that it has not always enjoyed such sweeping powers. During the 1980s there were clear attempts by reformists to limit its functions, and for a period after 1988 the zhengfawei was replaced by a much weaker Politics and Law Leading Small Group (zhengfa lingdao xiaozu 政法领导小组). ${ }^{\left({ }^{8}\right)}$ After Tiananmen, however, the zhengfawei was revived for obvious reasons and underwent its first round of empowerment in the early 1990s. ${ }^{(9)}$ The need to purge Falun Gong became the pretext for the further strengthening of the weiwen machine in 1999, when the Leading Small Group for Stability Maintenance Work (zhongyang weiwen gongzuo lingdao xiaozu 中央维稳工作领导小组) was established. (10)

When Zhou Yongkang took charge of the zhengfawei in 2008, China was experiencing its "first peak" (diyige langjian 第一个浪尖) in the number of mass incidents (quntixing shijian 群体性事件). ${ }^{(11)}$ To extend the reach of his power, Zhou set about constructing a nationwide, full-coverage security infrastructure by establishing weiwen offices at all levels of government, even down to the county and township levels. (12) Powerful dynamics kept the monolithic system running. The assessment and promotion of officials was adjusted in such a way that the ability to preserve stability became a key criterion in performance evaluation. ${ }^{(13)}$ The introduction of the "one-ballot veto" (yipiao foujue 一票否决) policy means that cadres who fail to maintain stability can be punished even if they boast excellent records in economic performance. ${ }^{(14)}$ The skewed logic of "smoothing things out shows competence; getting things done means stability; zero incident demonstrates ability" (baiping jiushi shuiping, gaodingjiushi wending, meishi jiushi benshi 摆平就是水平、搞定就是稳定、没事就是本事) generates strong incentives that predispose officials to use any means available to stamp out unrest at its first signs (loutou jiuda 露头就打) in order to secure career advancement. This suppressive approach has inevitably led to the perverse outcome of exacerbating tensions and inciting more disruptive protests.

Despite its apparent inefficacy, not to mention the significant cost to citizen's rights and the rule of law, both local and central governments have developed interests in the system's continued operation. For local officials, in addition to political achievements (zhengji 政绩), there are financial rewards to be reaped. The purported need to contain "threatening" individuals such as activists allows local security bureaus to come up with bigger budgets and demand special earmarked funds. For example, before his escape, the "expenditure" of putting blind lawyer Chen Guangcheng under house arrest was 60 million yuan in 2011 alone and involved more than 100 local police and cadres. ${ }^{(15)}$ The sum was granted to the township government where Chen was held as a one-off transfer from the county, with multiple layers of interests deriving monetary benefits in between. ${ }^{(16)}$ Weiwen therefore brings in good money for local officials: arrests and detentions are made if only to keep the resources coming. The central government, for its part, can keep its hands clean by delegating the use of violence to local security forces. Should any violent acts against citizens be exposed, the central government can conveniently evade responsibility and indeed burnish its upright image by bringing punishment upon malfeasant local officials. (17)

Public opposition to stability maintenance has strengthened over the years. In 2010, the social development research group under the Depart- ment of Sociology of Tsinghua University published a first detailed academic report that presents a systematic critique of the skewed logic of weiwen (weiwen beilun 维稳悖论) and the vicious cycles it engendered. ${ }^{(18)}$ Adopting the unassuming title "Institutionalise interest representation to realise longterm social stability," the 30-page report is a concerted attempt by a group of scholars including Sun Liping, Shen Yuan, and others to draw attention to the dangers of "pursuing stability regardless of cost" (buxi daijia zhiqiu wending 不惜代价、只求稳定). The campaign-style approach (yundongshi zhili 运动式治理) to stability preservation, which relies on a rigid model of vertical command and political mobilisation (chuizhi mingling zhengzhi dongyuan 垂直命令、政治动员), has resulted in the substitution of unbridled power in place of the law (yiquan daifa 以权代法). This rampant disregard for the rule of law has contributed directly to the present condition of social deterioration to the worrying point of collapse (shehui kuibai 社会溃 败). The symptoms of imminent collapse, the scholars warn, are already here: executive power slipping out of control (xingzheng quanli shikong 行政权 力失控); complete lack of restraint for interest conglomerates (qiangshi liyi jituan siwu jidan 强势利益集团肆无忌惮); penetration of dark and evil forces in localities (difangwei hei'eshili suo shentou he kongzhi 地方为黑恶势力所 渗透和控制); and severe corrosion of social justice (shehui gongping zhengyi zaoshou yanzhong qinshi 社会公平正义遭受严重侵蚀).

The unbearably high cost of weiwen borne by local governments has also drawn widespread criticism. Decrying the "black hole" of the astronomical cost of weiwen (tianjia weiwen de wudidong 天价维稳的无底洞), a Guangming Ribao columnist noted that in many localities, weiwen expenses now equal or have exceeded the amount spent on social welfare. (19) In Guangzhou, 4.4 billion yuan was spent on stability preservation in 2007 compared with the 3.52 billion yuan devoted to social security. ${ }^{(20)}$ The situation is particularly dire in poorer inland regions, where local governments subject to high fiscal pressure are forced to cut back on welfare programs. In March 2012, weiwen expenses made headlines as public security spending was to increase by 11.5 percent to 700 billion yuan, compared with a

7. Willy Lam, "Chen Guangcheng fiasco shows dim prospects for political-legal reform," China Brief, Vol. 12, No. 10, 11 May 2012.

8. Zhou Yongkun, "Zhengfawei de lishi yu yanbian" (The history and evolution of the zhengfawei), Yanhuang Chunqiu, September 2012, pp. 7-14.

9. Zhou Yongkun, ibid.

10. Xie Yue, "The Political Logic of weiwen in contemporary China," Issues and Studies, Vol. 48, No. 3, September 2012, pp. 1-41.

11. According to one estimate, the number of organised mass incidents increased from 124,000 in 2008 to over 280,000 in 2009. Comparatively, there were about 87,000 incidents in 2005 . He Qinglian, "China's stability maintenance system faces financial pressure," China Rights Forum, December 2012.

12. Xie Yue, art. cit.

13. Xie Yue, art. cit.

14. Xie Yue, art. cit. On the one-ballot veto system and its pitfalls, see "Yipiao foujue bei lanyong" (The abuse of the one-ballot veto system), China Newsweek, No. 598, 28 January 2013.

15. Wang Nan, "Chen Guangcheng zaoyu baoguang weiwen jingjiquan" (The Chen Guangcheng episode exposes the economy of weiwen), Voice of America, 1 May 2012, www. voanews.com/chinese/news/20120502_for_local_officials_suppressing_chen_is_also_a_business_endeavor-149907315.html (consulted on 25 January 2013).

16. Wang Nan, ibid.

17. Peter Mattis, "Zhou Yongkang and the tarnished reputation of China's police," China Brief, Vol. 12, No. 7, 30 March 2012.

18. Social Development Research Group, "Yi liyi biaoda zhidu huashi xian shehui de changzhi jiu'an" (Institutionalise interest representation to realise long-term social stability), Tsinghua University, April 2010.

19. "Tianjia weiwen de wudidong you duoshen?" (The bottomless pit of stability maintenance cost), Guangming Ribao, 9 June 2010.

20. Guangming Ribao, ibid. 
defence budget of 670 billion yuan. (21) Analyst He Qinglian estimates that at least 80 percent of this is expected to fund organs of state-sanctioned violence, with the majority going to public security departments and the paramilitary police. (22)

Critics also attack the flawed logic underlying the suppressive approach to stability preservation. Lawyer Chen Youxi argues that the weiwen governmentality mistakenly treats citizens as enemies of the state and as the ignorant mass (buming zhenxiang de qunzhong 不明真相的群众), and hence adopts Machiavellian (quanmoushi 权谋式) methods that do not attend to the roots of popular discontent. Chen also criticises the superstitious faith in police power (mixin gongquanli 迷信公权力) as naïve and shortsighted. (23) Critic Xia Nan similarly attacks the perverse drive to achieve absolute stability (dui juedui wending de bingtai zhuiqiu 对绝对稳定的病态追 求). To Xia, the overriding imperative to "resolve conflicts at the bottommost level" (ba maodun huajie zai jiceng 把矛盾化解在基层) contributes directly to the worrying normalisation of abusive tactics in the training of grassroots officials to the point of moral insensitivity. (24)

The purging of Bo Xilai and the reappraisal of his dahei (打黑) campaigns in Chongqing have opened a window for more of such dissenting views. Victims' accounts of the abuses they suffered as a result of unchecked power in Chongqing provided a strong basis for calls for reform. (25) In May, a group of veteran Communist Party members wrote to $\mathrm{Hu}$ jintao urging the sacking of Zhou Yongkang. ${ }^{26)}$ Hu's work report at the $18^{\text {th }}$ Party Congress and the White Paper on Judicial Reform released in October 2012 also offer hopeful signs of greater emphasis on the rule of law. ${ }^{(27)}$

\section{Reinventing social governance}

The extent of actual change, however, remains unclear. On the positive side, the downgrading of the zhengfawei secretary position implies an unambiguous curtailment of the power of Zhou Yongkang's successor, Meng Jianzhu. Meng is no longer "his own judge," as he will "have to answer to someone" in the PSC. ${ }^{(28)}$ There are also rumours that the Ministry of State Security may be taken from the zhengfawei structure and be placed under the control of the State Council, a move that would certainly weaken Meng further. ${ }^{(29)}$

At the regional level, signals are more mixed. On the one hand, there appears to be a retrenchment of zhengfaiwei power. As of January 2013, only seven heads of provincial public security bureaus serve concurrently as the provincial zhengfawei secretaries. ${ }^{(30)}$ On the other hand, new regional chief appointments still demonstrate preference for officials with weiwen experience. Wang Rulin and Xia Baolong, recently promoted from governor to provincial Party secretary of jilin and Zhejiang respectively, had both worked as provincial zhengfawei secretary previously. ${ }^{(31)}$ Even the records of socalled new stars of "sixth-generation" leaders are patchy at best. Hu Chunhua, the 49-year-old new Party secretary of Guangdong Province, was previously the party chief of Inner Mongolia, where he was recognised for the "successful" quelling of ethnic protests by Mongol minorities. His transfer to Guangdong has raised suspicion that Beijing is prepared to introduce a more strong-handed approach in disciplining the wilful province.

Looking ahead, one notable development is the renewed emphasis on social management (shehui guanli 社会管理). The phrase leapt to widespread attention after Hu Jintao's speech in February 2011, in which he called for the innovative construction of a "socialist social management system with Chinese characteristics" to "ensure a harmonious and stable society." In the same year, the Central Commission for Comprehensive Management of Public Security (Zhongyang shehui zhi'an zonghe zhili weiyuanhui中央社会治 安综合治理委员会) was renamed the Central Commission for Comprehensive Social Management (Zhongyang shehui guanli zonghe zhili weiyuanhui 中央社会管理综合治理委员会), in short the zongzhiwei. The renaming was accompanied by an expansion of the zongzhiwei apparatus by the addition of 11 new subdivisions, such that the organ now boasts 51 departments. According to Century Weekly, many provinces have in the past year raised the agency's profile by making their provincial Party secretaries or deputy Party secretaries the chairs of the zongzhiwei. (32) At the municipal level, there are cases in which the Party secretary and the mayor serve as dual heads the zongzhiwei (shuangzhurenzhi 双主任制).

In the official rhetoric, social management is to bring about a more service-oriented approach in governance that stresses neighbourhood building (shequ jianshe 社区建设) and the fostering of social organisations (shehui zuzhi 社会组织). Nonetheless, as Sebastian Veg observes, the empowerment of society, instead of entailing a relaxation of control, may in fact signal a transition to a new style of governance in which "carefully vetted non-governmental structures are employed to pull certain sectors of society into the orbit of the state, and then ultimately outsource control of society to them." (33)

Notably, the reinvigorated zongzhiwei enjoys close ties with the zhengfawei and its subsidiaries. In many localities the two organs share the same staff and offices (heshu bangong 合署办公). The practice of top "first-in-command" officials (yibashou 一把手) holding leadership positions across several departments is ubiquitous. Before the regional chief reshuffle, in Hebei, Anhui, and Yunnan provinces the zhengfawei head serves as the concurrent chief of public security and the zongzhiwei. In other localities, it is not uncommon for public security chiefs, high people's court presidents, the procurator-generals, and even military personnel to serve concurrently as deputy directors of the zongzhiwei. The zongzhiwei thus enjoys broad cross-departmental powers in the Party, the government, and the military, useful, no doubt, for "organisation and coordination" (zuzhi xietiao 组织协调) of efforts to "max-

21. "700b yuan bill to guard against enemy within," Reuters, 6 March 2012.

22. He Qinglian, ibid.

23. Chen Youxi, "Gaoyaweiwen de cuowu" (The mistakes of suppressive stability maintenance), Economic Observer, 26 December 2011.

24. Xia Nan, "Yihua de weiwen" (Alienated stability maintenance), Caijing, 12 September 2011.

25. For such accounts see for example the four-part series run by South China Morning Post on Bo Xilai's campaigns in Chongqing, the first piece being Keith Zhai, "In the dungeon of Bo Xilai," SCMP, 19 December 2012.

26. Michael Bristow, "China veterans urge sacking of Zhou Yongkang," BBC, 16 May 2012.

27. Carl Minzner, ibid.

28. Chris Buckley, "Exclusive: China considers downgrading domestic security tsar in next line-up," Reuters, 29 August 2012.

29. Peter Mattis, "Year-end questions on political-legal reform," China Brief, Vol. 13, No. 24, 14 October 2012.

30. The seven provinces are Anhui, Hebei, Gansu, Ningxia, Jiangxi, Hunan, and Guizhou. "Shengji zhengfa renshi tiaozheng kaiju" (Reshuffle begins for provincial-level zhengfawei personnel), Caixin, 6 January 2013, http://china.caixin.com/2013-01-06/100480037.html (consulted on 25 January 2013).

31. Willy Lam, "Regional chief selections highlight continuity in leadership development," China Brief, Vol. 13, No. 1, 4 January 2013.

32. Chen Baocheng, "Zongzhiwei bianshen yiniankao" (Assessing the zongzhiwei one year after its transformation), Century Weekly, 21 September 2012. Information on the makeup of zongzhiwei leadership in the rest of this paragraph is taken from the same article.

33. Sebastian Veg, "Over Eighteen: China's Political Spectrum Today," The China Story, 15 January 2013, www.thechinastory.org/2013/01/over-eighteen-chinas-political-spectrum-today/ (consulted on 25 January 2013). 
imise factors conducive to harmony and minimise those detrimental to it." (34) In light of the delegitimisation of the zhengfawei and the public security apparatus, the rise in stature of the zongzhiwei and the growing currency of social management as the new political jargon are noteworthy and raise the important question of whether they serve as a reinvented form of social control. (35)

\section{Reforming institutions of repression}

The $18^{\text {th }}$ Party Congress era may also see progress in reforming some institutions of violence operating at the bottom of the production chain (chanyelian 产业链) of weiwen. These institutions, legal or extralegal, serve the specific function of helping local governments take deviant individuals - petitioners, protest participants, human rights activists - off the streets in order to preserve social order. This paper discusses three of these institutions, namely the re-education through labour system, the mental health institutions, and the nationwide network of black jails, and evaluates recent attempts towards bringing these institutions under the rule of law.

\section{Re-education through labour}

One of the most notorious institutions in the stability maintenance apparatus is the re-education through labour (laodong jiaoyang 劳动教养) system, commonly known as laojiao. Modelled after the Soviet Gulag, the system was initially established in the mid-1950s to incarcerate those arrested in the Campaign to Suppress Counterrevolutionaries (zhenya fange ming yundong 镇压反革命运动) that took place in the early 1950s. (36) It was soon used by Mao Zedong to confine opponents during the Anti-Rightist Movement (fanyou yundong 反右运动) and to detain criminal offenders. The arbitrary regulations turned the system into a convenient instrument for local units from communes to production brigades. The number of those receiving labour reform increased from 36,983 in 1957 to almost 500,000 in 1960. (37) The use of laojiao declined during the Cultural Revolution, but the institution was vigorously revived, expanded, and indeed legalised through a series of notices and regulations announced in the late 1970s and early 1980s. There has since been "a vast explosion in the number of offenses that can lead to laojiao," as the system was deployed against democracy protesters after the 1989 Tiananmen crackdown, practitioners of Falun Gong and other religious groups, and those who resisted the onechild policy. ${ }^{(38)}$

Today, the laojiao system can place a person behind bars for three years without trial and in some cases four if the person is considered "insufficiently re-educated." (39) A United Nations Human Rights Council report estimated in 2009 that there were some 190,000 Chinese held in 320 re-education centres nationwide. A Ministry of Justice expert put the figure at 60,000 as of January 2013 , in addition to 200,000 former drug addicts. ${ }^{(40)}$ Conditions within laojiao centres, managed by the Ministry of Justice, are notoriously poor and condemned by some as "essentially unmonitored sweatshops" where inmates are reportedly forced to work 12-hour shifts doing heavy construction work for private developers. ${ }^{(41)}$

With heightened emphasis on stability maintenance, laojiao is now systematically used against petitioners and activists. With the police in charge of imposing sentences, the system provides "a handy tool for dispensing punishment without intrusions by lawyers or judges," allowing local governments to take a large number of "trouble-makers" off the streets conve- niently. The most controversial case recently involved Tang Hui from Hunan Province, the mother of an 11-year-old girl who was kidnapped, raped, and sold into prostitution by seven men. Tang was sent to laojiao for 18 months for repeatedly petitioning local authorities to bring harsher punishment upon the perpetrators. She was released within a week after her case drew widespread attention online. Another widely publicised case involved 25year-old former village official Ren Jianyu, who was given a two-year laojiao sentence for spreading "negative comments and information" on the Internet and for mocking Bo Xilai's red campaign as a return of the Cultural Revolution. ${ }^{(42)}$ Ren was released nine months early, but the lawsuit he filed against the Chongqing Laojiao Committee to defend his innocence was rejected. ${ }^{(43)}$

The call to reform the disputed system came to the forefront before the $18^{\text {th }}$ Party Congress meetings. In October 2012, Jiang Wei, the official in charge of the Central Leading Small Group for Judicial Reform, announced that the authorities had "reached a consensus" on the necessity to reform the system, in particular the approval procedure in which authorities decide if a person should receive laojiao. In January 2013, Xinhua and other government mouthpieces reported that Meng Jianzhu, the new zhengfawei secretary, will explore the possibility of abolishing laojiao within this year. In fact, pilot testing of a replacement system called "education and correction of violations" (weifa xingwei jiaoyu jiaozhi 违法行为教育矫治) already began in August in the cities of Nanjing, Lanzhou, Zhengzhou, and Jinan. (44) It remains to be seen whether this substitute - reportedly a smaller-scale variant with more reasonable procedures - represents something fundamentally different or merely "a deceptive name change." (45) Indeed, it is not the first time that laojiao reform has been put forward since its reinstallment. Proposals to abolish the system had emerged as early as the mid 1980s. In 2003, seven members of the Guangdong committee of the Chinese People's Political Consultative Conference proposed experimenting with abolition in the province. By 2007 , at least 420 representatives of the

34. Full text of $\mathrm{Hu}$ Jintao's report at the 17th Party Congress, http://news.xinhuanet.com/ english/2012-03/26/c_131489727_8.htm (consulted on 25 January 2013).

35. For more on social management, see David Cohen, "Decoding 'social management'," The Diplomat, 21 September 2011, http://thediplomat.com/china-power/decoding-social-management/(consulted on 25 January 2013); Joseph Fewsmith, "'Social management' as a way of coping with heightened social tensions," China Leadership Monitor, No. 36, 2012; Samantha Hoffman, "Portents of change in China's social management," China Brief, Vol. 12, No. 15, 4 August 2012.

36. Zhou Yongkun, "Laojiao zhidu de lishi yu feichu husheng" (The history of the re-education through labour system and the calls for its abolition), Yanhuang Chunqiu, December 2012, pp. $22-28$.

37. Zhou Yongkun, ibid.

38. Stanley Lubman, "Re-examining re-education through labour," Wall Street Journal, 11 September 2012, http://blogs.wsj.com/chinarealtime/2012/09/11/examining-chinas-re-education-onlabour-camps/ (consulted on 25 January 2013); Mark Magnier, "China thinks of closing its reeducation prisons," Los Angeles Times, 5 March 2007, http://articles.latimes.com/ 2007/mar/05/world/fg-reeducate5 (consulted on 25 January 2013).

39. Zhao Yinan, "Re-education through labour under review," People's Daily, 10 October 2012, http://english.peopledaily.com.cn/90882/7972615.html (consulted on 25 January 2013).

40. "Ministry of Justice expert: 60,000 Chinese currently receiving laojiao," Nandu News, 7 January 2013, http://ndnews.oeeee.com/html/201301/07/14439.html (consulted on 25 January 2013).

41. Mark Magnier, ibid.

42. Bai Tiantian, "'Red song' detention appealed," Clobal Times, 11 October 2012, www.globaltimes.cn/content/737605.shtml (consulted on 25 January 2013).

43. "Shenshi laojiao" (Assessing re-education through labour), China Newsweek, No. 590, 29 November 2012.

44. "Cities pilot alternative to 're-education through labour'," Economic Observer, 29 August 2012, www.eeo.com.cn/ens/2012/0829/232678.shtml (consulted on 25 January 2013). See also Stanley Lubman, ibid.

45. Andrew Jacobs, "Labour camp critics spread in China," International Herald Tribune, 17 December 2012. 
National People's Congress had tabled proposals to change the disreputable system. ${ }^{(46)}$ Abolishing the system will entail a redistribution of power and will likely weaken the public security apparatus. Whether sufficient momentum has finally been gathered for substantive change remains to be seen.

\section{Mental health institutions}

One definite step towards tighter oversight has been made in the area of mental health institutions. On 26 October 2012, China adopted the country's first Mental Health Law (jingshen weisheng fa 精神卫生法) in an explicit attempt to address the disturbingly prevalent phenomenon of healthy individuals being declared mentally ill and committed to psychiatric facilities for political reasons (bei jingshenbing 被精神病). According to news portal Caixin, at least 300,000 people were forcibly sent to mental hospitals in 2008. ${ }^{(47)}$ These institutions are seen not merely as medical institutions, but troublingly also as disciplinary and law enforcement bodies targeting disturbers of social order. Other than the health and civil affairs departments, the police department is also responsible for operating mental wards. ${ }^{(48)}$ The Ministry of Public Security operates its own infamous system of Ankang Hospitals (ankang yiyuan 安康医院), where no court order is required for committal. ${ }^{(49)}$

The practice of politically motivated psychiatric custody has been in existence since the early 1950s as China learnt from the network of Special Psychiatric Hospitals operated by the Soviet Union's Ministry of the Interior. ${ }^{(50)}$ In the 1990s, attention was drawn to the secretive operation as Human Rights Watch accused China of using it against Falun Gong members and political dissidents. Nowadays, according to a database compiled by a Chinese human rights organisation, petitioners are the most frequent victims. In one revealed case, repeated petitioning was even put down as the sole cause for confinement. ${ }^{(51)}$ The conspicuous lack of unified regulation on mental facilities means that hospitals are free to draw up their own rules, resulting in rampant abuse of inmates using medical means, including extreme dosages of medication, injections, and application of electricallycharged acupuncture needles. In a case reported by the New York Times, farmer Xu Lindong was locked up for more than six years, during which he received 54 electric-shock treatments in addition to routine injections of powerful drugs. His initial "crime" was repeated filing of complaints against the local government over a land dispute. ${ }^{(52)}$ Another man in Hubei Province was confined to a mental ward for nearly 14 years for exposing corruption in the government. ${ }^{(53)}$

Drafting of the Mental Health Law began as early as 1985, but it was only in June 2011 that the first draft was issued. (54) The draft contains several highly contentious provisions. ${ }^{(55)}$ For example, Articles 26 and 27 allow individuals who are suspected of having mental illness to be involuntarily committed when they exhibit behaviour that threatens public security (weihai gonggong anquan 危害公共安全) or disturbs public order (raoluan gonggong zhixu 扰乱公共秩序). ${ }^{(56)}$ Article 24 empowers close relatives to send a suspected mentally disabled family member to the hospital, which makes them vulnerable targets of external pressure. While this latter article remains unchanged in the final version (as Article 26), the passed law does introduce tighter regulations to prevent involuntary committal, including granting patients the right to ask for re-evaluation by a qualified psychiatrist of their choice if they do not agree with the initial diagnosis. Individuals can also lodge lawsuits against the government or medical institutions if their legal rights have been harmed.
It is unclear whether this step forward by the central government will be implemented at the local level. As of 2010, only six out of 283 cities have a local mental health ordinance. ${ }^{(57)}$ Local authorities appear undeterred in using mental health as a tactic to spot potentially "unstable" individuals. The South China Morning Post reported in October that community health centres across Shanghai were given orders to conduct psychiatric surveys in which local residents were asked to identify persons in their neighbourhoods who fight with others, talk in riddles, speak or laugh to themselves, or show odd facial expressions. Talking too much, meddling in others' affairs, and being cold towards others are also marked as signs of mental instability. ${ }^{(58)}$ Activist Wan Yanhai noted similar developments in Zhejiang Province, and expressed concern for "a troubling return to the climate of suspicion" experienced during the Cultural Revolution, when neighbours were encouraged to report on one another. ${ }^{(59)}$ These latest developments are poignant reminders that laws passed at the national level remain fragile and irrelevant at best when local governments have little incentive for their implementation.

\section{Black jails}

A third network of extrajudicial institutions that has expanded significantly in the 2000s is the operation of unlawful detention facilities commonly known as black jails (heijianyu 黑监狱) or black houses (heifangzi 黑房子). Like labour camps and mental hospitals, black jails are used to take undesirables off the streets and limit destabilising activities. Specifically, they target petitioners who make their way to provincial capitals and Beijing from different parts of the country in the hope of presenting their grievances before higher-level authorities. As a larger number of petitioners signals a weaker ability on the part of local officials to resolve conflicts within their jurisdiction, which adversely affects their career prospects, local officials employ "interceptors" to abduct petitioners en route to or at the capital. (60) These interceptors, usually thugs hired by security companies, hold petitioners captive at secretive locations such as hostels and abandoned sites

46. Zhou Yongkun, ibid.

47. Du Liya, "Activists hail court ruling," Global Times, 10 October 2012.

48. Wan Yanhai, "The Madness of China's mental health system," Foreign Policy, 26 January 2011.

49. Robin Munro, "The Ankang: China's Special Psychiatric Hospitals," Journal of Comparative Law, Vol. 1, No. 1, 2005, pp. 41-87.

50. Robin Munro, ibid.

51. Sharon LaFraniere and Dan Levin, "Assertive Chinese held in mental wards," New York Times, 11 November 2010.

52. After three suicidal attempts, Xu was released in April 2010 with a compensation of 300,000 yuan. Sharon LaFraniere and Dan Levin, ibid.

53. "Internet post frees man confined 14 years in mental hospital," Xinhua, 8 January 2011, www.china.org.cn/china/2011-01/08/content_21697817.htm.

54. Full draft of Mental Health Law, www.law-lib.com/fzdt/newshtml/20/2011061109 1442.htm (consulted on 25 January 2013).

55. Elizabeth M. Lynch, "Analysis of Chinas draft mental health law - an Interview," China Law and Policy, 24 October 2011, http://chinalawandpolicy.com/2011/10/24/analysis-of-china\%E2\%80\% 99s-draft-mental-health-law-\%E2\%80\%93-an-interview/ (consulted on 25 January 2013).

56. These phrases are removed from the final version. Full text of Mental Health Law, www.npc. gov.cn/huiyi/cwh/1129/2012-10/27/content_1741177.htm.

57. Sharon LaFraniere and Dan Levin, ibid.

58. Alice Yan, "Shanghai citizens quizzed on friends' mental health," SCMP, 17 October 2012.

59. Wan Yanhai, ibid.

60. According to unpublished local government documents, penalties are levied against local officials who are unable to take decisive measures to prevent petitioners from their geographical jurisdiction from seeking legal redress in provincial capitals and Beijing. See "China: Secret 'black jails' hide severe rights abuses," Human Rights Watch, 12 November 2009. 
until they received notice to send them back home. ${ }^{(61)}$ Such extralegal activities intensify and reach their peak every year during the Two Meetings (lianghui 两会) of the National People's Congress and Chinese People's Political Consultative Conference. ${ }^{(62)}$

Ironically, one direct cause for the recent growth of black jails is the abolition of the arbitrary Custody and Repatriation (shourong qiansong 收容遣送) procedure, a vagrancy detention system complemented by 700 official shourong centres nationwide that allowed the police to arrest, detain, and repatriate any citizen on the streets without a local hukou (户口) registration. ${ }^{(63)}$ In 2003 , the outpouring of public outrage over the tragic death of migrant student Sun Zhigang as a result of abuse at a shourong centre in Guangzhou forced the central government to abolish Custody and Repatriation. The closure of facilities did not effectively bridle the police's acquired powers of arbitrary detention, however, but merely prompted the proliferation of extralegal black jails and drove outlawed practices underground. Since 2003, the operation of black jails has evolved into a lucrative business sustained by intertwined chains of interests. In one uncovered case, the private security firm Anyuanding has expanded significantly since its launch in 2004, attracting more and more clients "including even remote village governments." (64) Local officials, intent on eliminating any disruptions that may jeopardise their political careers, are willing to hire thugs, commonly known as retrievers (jiefangrenyuan 截访人员), to abduct petitioners, paying as much as US\$250 for each person successfully captured. Black jail operators, on the other hand, receive daily cash payments from local governments for each detainee, with a different charge imposed for urban and rural petitioners. ${ }^{(65)}$

Despite irrefutable evidence, officialdom has remained staunchly in denial of the existence of black jails. When challenged by overseas media, the Foreign Ministry spokesperson replied with a curt "Things like this don't exist in China." (66) To maintain the official silence, exposed cases were either quickly censored or declared isolated incidents. ${ }^{(67)}$ In the 2010 Anyuanding case, two executives were arrested but later released without charge. The Beijing police even raided the office of Caijing magazine as a retributive punishment for reporting the story. ${ }^{(68)}$ More recently, in December 2012, Xinhua and People's Daily reported on a Beijing court sentencing ten people to jail for illegally detaining and assaulting a group of petitioners from Henan, but the reports were mysteriously taken down by the end of the day. ${ }^{(69)}$

In an unusual turn of events, it was reported that on 6 December 2012, hundreds or even thousands of petitioners were released from one of Beijing's largest black jails. That this unexpected move took place on Rule of Law Promotion Day was seen by some as a sign that the new Xi-Li leadership is resolved to curb illegal imprisonment. ${ }^{(70)}$ The earlier approval by China's legislature in March 2012 of amendments to the Criminal Procedure Law, however, offers a less optimistic view. Despite measures to strengthen the rights of suspects, including the prohibition of the use of violence in obtaining evidence and compulsory taping of interrogation procedures, the newly revised law contains a provision that effectively allows individuals to be kept away from home in secret locations for an unspecified amount of time. The controversial Article 73, dubbed "disappearance clause" or "KGB clause," confers power on law enforcement agencies to detain those suspected of involvement in cases related to corruption, terrorism, or "national security" - which has in the past been interpreted loosely to include acts such as criticising the government. ${ }^{\left({ }^{11}\right)}$ According to the revised law, family members must be notified within 24 hours, but this protection does not apply if they cannot be reached or, arbitrarily, when it is deemed that noti- fication hinders investigations. ${ }^{(72)}$ The incorporation of Article 73 into the revised law, as Human Rights Watch's Nicholas Bequelin suggests, solidifies the supremacy of the security state and demonstrates that hard-line and conservative elements within the Party remain strong. ${ }^{(73)}$

\section{Whither weiwen?}

Bringing substantive reform to the above institutions of violence would require, at the very least, a fundamental change in the standards of cadre evaluation. For local governments, all three institutions serve as convenient means to reduce the number of troublemakers and maintain outward social stability. As long as these objectives continue to dominate career advancement considerations, local officials will have a strong incentive to resort to such arbitrary and extralegal measures in order to secure political achievements. Reform at the level of national legislation without correcting the perverse incentive structure is likely to prove ineffective. However, the central leadership, as we have seen, also benefits from such an arrangement as it allows them to avoid responsibility for violent clampdowns by making scapegoats of its local agents. Hence, bidding farewell to the weiwen governmentality would require new thinking on governance on the part of Beijing.

Right now, there are signs that weiwen will turn into a more insidious form of control that, by entering the world of the press and the Internet, is able to cut off attempts to organise collective actions before they reach the streets. According to one estimate, the city of Beijing is currently spending some 40 million yuan a month on stability maintenance on the blogosphere (wangluo weiwen 网络维稳), and boasts a 2 million strong team of Internet commentators (wumao 五毛). ${ }^{(74)}$ Earlier in March 2012, the authorities made the controversial move of launching real-name registration for microblogs (weibo). Netizens must register their real names, and in some cases

61. On the conditions in black jails, see the investigative reports "China's 'black jails' uncovered," $A l$ Jazeera, 27 April 2009; Melissa Chan, "Seeking answers inside China's 'black jails'," Al Jazeera, 13 March 2012; Aidan Hartley, "The terrible secrets of Beijing's 'black jails'," The Spectator, 10 October 2007; Lara Farrar and Kevin Voigt, "Chinese petitioners claim hotel used as 'black jail'," CNN, 14 November 2012.

62. Xu Zhiyong, "The Plight of a young Chinese volunteer," Seeing Red in China, 12 July 2012, http://seeingredinchina.com/2012/07/23/the-plight-of-a-young-chinese-volunteer-by-xu-zhiyong/ (consulted on 25 January 2013).

63. Human Rights Watch, An Alleyway in Hell: China's abusive "black jails," November 2009.

64. "'Black jails' investigated for illegally holding petitioners," China Daily, 27 September 2010.

65. According to Xu Zhiyong, local governments pay 200 yuan for a city petitioner per day and 150 for a rural petitioner per day. Human Rights Watch, ibid., p. 14. In one revealed case, released petitioners said they were held according to where they come from, i.e., within the black jail there is a hall for holding petitioners from Zhejiang, a separate hall for petitioners from Shandong, etc. Mandy Zuo and Shi Jiangtao, "Many freed from Beijing's biggest 'black jail'," SCMP, 6 December 2012.

66. "China's 'black jails' uncovered," Al Jazeera, 27 April 2009.

67. In 2011, a black jail was discovered in the Changping district of Beijing and subsequently dismantled. The publicity official of the municipal public security bureau said it was an individual case and that there was no other illegal detention house in the entire city. Wang Huazhong, "Former inmate reveals existence of new 'black jail'," China Daily, 3 August 2011.

68. Phelim Kine, "Beijing's Black Jails," Foreign Policy, 15 March 2012.

69. Andrew Jacobs, "'Black jail' verdict that never was," New York Times, 2 December 2012.

70. Mandy Zuo and Shi Jiangtao, ibid.

71. "China passes new law allowing secret detentions," CNN, 14 March 2012.

72. "Article 73 sparks controversy on secret detentions," Caixin, 12 March 2012.

73. Nicholas Bequelin, "Legalizing the tools of repression," International Herald Tribune, Global Opinion, 29 February 2012.

74. "Beijing wumao erbaiwan ren?" (Beijing has 2 million Internet commentators?), House News, 18 January 2012, http://thehousenews.com/politics/\%E5\%8C\%97\%E4\%BA\%AC-\%E4\%BA\%94\%E6 \%AF\%9B-\%E4\%BA\%8C\%E7\%99\%BE\%E8\%90\%AC\%E4\%BA\%BA/ (consulted on 25 January 2013). 
submit their personal IDs and telephone numbers, before they are allowed to create posts. ${ }^{(75)}$ In December 2012, the Chinese Academy of Social Sciences published the Blue Book of China's Society 2013, which draws attention to the power of the mobile Internet in mobilising citizens. In a rare reference to Hong Kong, the report mentions the large-scale civic movement against national education, which, it says, "was rather unexpectedly instigated by three high school students through Facebook." (76) In light of the "impulsive and radical behaviour" of some mainland young people in anti-pollution and anti-Japanese demonstrations, which have caused "anxiety and controversy in the society," the report calls on the government to more tightly supervise online public opinions in order to realise weiwen. ${ }^{(77)}$ Strengthening Internet regulations is also called for to target "irresponsible rumours" on the Internet (bu fuzeren de yaoyan 不负责任的谣言), although the report does praise the recent online campaign against corrupt officials (wangluo fanfu lüjian qigong 网络反腐屡建奇功). ${ }^{(78)}$
It remains to be seen whether the new administration headed by Xi jinping and Li Keqiang will heed such advice and move towards a stricter regime of stability maintenance in the media. The Nanfang Zhoumo incident at the beginning of the year, deemed "the first big political scandal of 2013," is a distressing reminder of the pressure to which the media continue to be subject. ${ }^{(79)}$ The burden is on $\mathrm{Xi}$ to bring about genuine change in the $18^{\text {th }}$ Party Congress era.

I Karita Kan is a doctoral student in politics at the University of Oxford and is currently a research assistant at CEFC (karitakan@gmail.com).

CEFC News Analysis is compiled from the CEFC's fortnightly selection of Press Highlights, available at www.cef.com.hk.
75. "Weibo launches real-name registration," Global Times, 15 March 2012.

76. On the anti-national education protests in Hong Kong, please refer to the CEFC current affairs analysis in the December 2012 issue.

77. "Report urged China to supervise online public opinions to preserve stability" (Baogao cu Zhongguo jiancha wangluo shixian weiwen), BBC, 18 December 2012.

78. "Public Opinion in the virtual world," Ming Pao editorial, 20 December 2012.

79. On the Nanfang Zhoumo incident, please refer to the press meeting notes for 11 January 2013 available on the CEFC website. 